\title{
KOREKSI BIAS STATISTIK PADA DATA PREDIKSI SUHU PERMUKAAN AIR LAUT DI WILAYAH INDIAN OCEAN DIPOLE BARAT DAN TIMUR
}

\author{
Mohamad Khoirun Najib ${ }^{\mathrm{a}}$, Sri Nurdiati ${ }^{\mathrm{a}}$ \\ a Departemen Matematika, IPB University, Jl. Meranti, Bogor 16680, Indonesia
}

\section{ARTICLE INFO}

\section{Article history:}

Received: 24 November 2020

Accepted: 13 January 2021

Published: 19 January 2021

\section{Keywords:}

Bias Correction; ECMWF; Indian Ocean Dipole; Quantile Mapping

\section{Corresponding author:}

Mohamad Khoirun Najib

IPB University, Bogor, Indonesia

Email: mkhoirun_najib@apps.ipb.ac.id

\begin{abstract}
The IOD can be measured using the Dipole Mode Index (DMI) which is calculated based on the sea surface temperature in the Indian Ocean. Therefore, DMI can be predicted using sea surface temperature forecasting data, such as data that provided by the European Center for Medium-Range Weather Forecasts (ECMWF). However, the data still has bias as compared to the actual data, so to get a more accurate prediction, corrected data is needed. Therefore, this study aims to correct the bias of the sea surface temperature forecasting data in the west and east IOD regions using the quantile mapping method, a method that connects the distribution of forecasting and actual data, then from the results of the correction, the IOD index prediction value and its accuracy value will be calculated. The results showed that the DMI prediction using ECMWF data after correction was more accurate than the DMI prediction using ECMWF data before correction. Moreover, DMI predictions using corrected data have high accuracy to predict IOD events in October-April.
\end{abstract}

Copyright (C) 2021 The Authors This open access article is distributed under a Creative Commons Attribution (CC-BY) 4.0 International license

\section{Pendahuluan}

Indian Ocean Dipole (IOD) menunjukkan kondisi laut-atmosfer yang berada di Samudra Hindia. Kondisi tersebut diukur menggunakan suatu indeks yang dinamakan Dipole Mode Index (DMI) yaitu selisih antara anomali suhu permukaan laut di Samudra Hindia barat $\left(50^{\circ} \mathrm{BT}-70^{\circ} \mathrm{BT}, 10^{\circ} \mathrm{LS}-10^{\circ} \mathrm{LU}\right)$ dan timur $\left(90^{\circ} \mathrm{BT}-110^{\circ} \mathrm{BT}, 10^{\circ} \mathrm{LS}-0^{\circ} \mathrm{LU}\right)$ (Saji et al., 1999). Dikutip dari www.bom.gov.au, ketika DMI bernilai lebih dari +0.4 , kondisi tersebut disebut IOD positif. Pada fase IOD positif, kolam hangat akan bergeser ke pantai Afrika dan suhu permukaan laut di Indonesia bagian barat menjadi dingin yang mengakibatkan penurunan tingkat kondensasi dan curah hujan, sehingga terjadi musim kering. Sebaliknya, kondisi IOD negatif (yaitu ketika DMI bernilai kurang dari -0.4) akan mengakibatkan musim basah di Indonesia (Bramawanto \& Abida, 2017). Karena DMI dihitung berdasarkan suhu permukaan laut di Samudra Hindia, prediksi DMI juga dapat dihitung berdasarkan data prediksi suhu permukaan air laut di Samudra Hindia.

Data prediksi suhu permukaan laut telah banyak tersedia. Salah satunya adalah data yang disediakan oleh lembaga European Centre for Medium-Range Weather Forecasts (ECMWF). ECMWF menyediakan banyak data prediksi cuaca seperti curah hujan, kecepatan angin, kelembapan, dan suhu permukaan laut dalam jangka waktu harian, bulanan hingga musiman. Namun, data yang disediakan oleh ECMWF tersebut masih memiliki bias terhadap data sebenarnya, termasuk data prediksi suhu permukaan air laut (Macias et al., 2018; Stockdale et al., 2011). Sebagian bias disebabkan oleh masalah dengan pengukuran itu sendiri. Selain itu, bias juga dipengaruhi oleh kesalahan dalam penghitungan transfer radiasi yang digunakan untuk mensimulasikan pengamatan pancaran dari status model (Dee, 2004). Kesalahan ini berbeda untuk setiap sensor dan setiap saluran, serta cenderung bergantung pada status instrumen (misalnya posisi pemindaian dan kalibrasi yang buruk) serta pada properti lokal dari parameter geofisika yang dirasakan (McNally et al., 2000). Proses untuk membersihkan data dari bias 
sehingga diperoleh data prediksi dengan bias yang minimal dan lebih akurat disebut dengan proses koreksi bias statistik (Dippe et al., 2019). Salah satu metode yang digunakan untuk koreksi bias statistik adalah metode quantile mapping (Piani et al., 2010). Metode quantile mapping atau sering disebut juga distribution mapping dinilai mampu memperbaiki data prediksi suhu permukaan air laut lebih baik dibandingkan metode koreksi bias statistik lain, seperti linear scalling dan variance scalling. (Nurdiati, Sopaheluwakan, \& Pratama, 2019)

Banyak peneliti telah menggunakan metode quantile mapping untuk mengoreksi bias dari data prediksi cuaca, seperti koreksi bias untuk data curah hujan di pulau Bali (Lealdi et al., 2018), data prediksi suhu permukaan air laut di wilayah Nino 3.4 (Nurdiati, Sopaheluwakan, \& Pratama, 2019) dan data selisih rataan prediksi suhu permukaan air laut di wilayah Indian Ocean Dipole (Nurdiati, Sopaheluwakan, \& Najib, 2019). Akan tetapi, belum ada peneliti yang mengoreksi data suhu permukaan air laut di IOD barat dan timur serta menghitung DMI dari prediksi suhu permukaan air laut tersebut. Oleh karena itu, penelitian ini bertujuan mengoreksi bias data prediksi suhu permukaan laut di wilayah IOD barat dan timur menggunakan metode quantile mapping, kemudian dari hasil koreksi tersebut akan dihitung nilai prediksi indeks IOD beserta nilai akurasinya. Penelitian ini diharapkan mampu memprediksi kejadian IOD dengan lebih akurat sehingga pemerintah dapat mempersiapkan kebijakan yang sesuai dengan kondisi iklim global yang akan datang.

\section{Metode}

\subsection{Jenis dan sumber data}

Data prediksi suhu permukaan laut yang digunakan adalah data ECMWF yang diperoleh dari Pusat Penelitian dan Pengembangan, Badan Meteorologi Klimatologi dan Geofisika (BMKG). Data tersebut memiliki resolusi spasial $0.25^{\circ} \times 0.25^{\circ}$ dari $1982-2018$ dalam format NetCDF. Pada setiap bulan, data ECMWF memiliki ukuran multi-dimensi yaitu bujur $\times$ lintang $\times$ ensemble $\times$ waktu dengan rincian IOD Barat $205 \times 45 \times 25 \times 216$ dan IOD Timur $205 \times 45 \times 25 \times 216$. Pemodelan ensemble adalah proses menjalankan dua atau lebih model analisis yang saling terkait namun berbeda, kemudian hasilnya disintesis menjadi satu nilai atau penyebaran untuk meningkatkan akurasi analisis prediktif dan aplikasi data mining (Buizza et al., 2008; Lealdi et al., 2018). Dengan demikian, data ECMWF yang dirilis setiap bulan memiliki jangkauan prediksi 216 hari ke depan atau sekitar 7 bulan. Untuk membaca data tersebut, diperkenalkan konsep lead times. Misalkan terdapat data ECMWF bulan Januari 2018 dengan jangkauan 7 bulan. Data pada hari ke-1 sampai 31 disebut sebagai data prediksi bulan Januari pada lead time ke-1 karena data dikeluarkan pada bulan yang sama. Sementara itu, data hari ke-32 sampai 59 disebut sebagai data prediksi bulan Februari pada lead time ke-2, karena data tersebut dikeluarkan ECMWF pada bulan Januari untuk memprediksi bulan Februari. Proses tersebut diulang hingga diperoleh lead time ke-7 (Ogutu et a1., 2017). Data kedua adalah data HadISST yang merupakan data interpolasi dengan akurasi yang tinggi dan digunakan untuk merepresentasikan data suhu permukaan air laut yang sebenarnya serta digunakan untuk menghitung DMI oleh NOAA. Data HadISST dapat diunduh pada situs web resmi http://www.metoffice.gov.uk/hadobs/hadisst/data/HadISST_sst.nc. Data ini digunakan sebagai data aktual. Kesenjangan antara data ECMWF dan HadISST ini yang disebut bias dan akan dikoreksi menggunakan metode quantile mapping. Data HadISST memiliki resolusi spasial $0.25^{\circ} \times 0.25^{\circ}$ dalam format NetCDF.

\subsection{Koreksi bias dengan metode quantile mapping}

Koreksi bias statistik merupakan teknik untuk mencari hubungan antara data prediksi dan data sebenarnya. Hubungan tersebut dapat direpresentasikan ke dalam suatu fungsi transfer dengan bentuk persamaan $y=f(x)$. Terdapat beberapa metode untuk melakukan koreksi bias statistik, salah satunya adalah quantile mapping. Metode quantile mapping akan menghubungkan kuantil dari CDF data prediksi dan data aktual. Terdapat tiga langkah untuk mengoreksi bias menggunakan metode quantile mapping (Misnawati et al., 2018). Pertama, data prediksi dan aktual diidentifikasi masing-masing distribusinya sehingga diperoleh fungsi kepekatan peluangnya (PDF). Kedua, PDF diintegralkan sehingga diperoleh fungsi sebaran (CDF) masing-masing. Ketiga, diambil nilai kuantil dari masing-masing CDF dan dibentuk fungsi transfer, yaitu $y=f(x)$ dengan $x$ dan $y$ masing-masing adalah kuantil dari data prediksi dan aktual. Ketiga proses tersebut masing-masing diilustrasikan pada Gambar 1(a), 1(b) dan 1(c). Setelah fungsi transfer diperoleh, data prediksi (data testing) dikoreksi dengan cara mengevaluasi data tersebut pada fungsi transfer yang diperoleh, yaitu

$X_{c}=f(X)$

dengan $X$ dan $X_{c}$ masing-masing adalah data prediksi sebelum dan sesudah dikoreksi. 

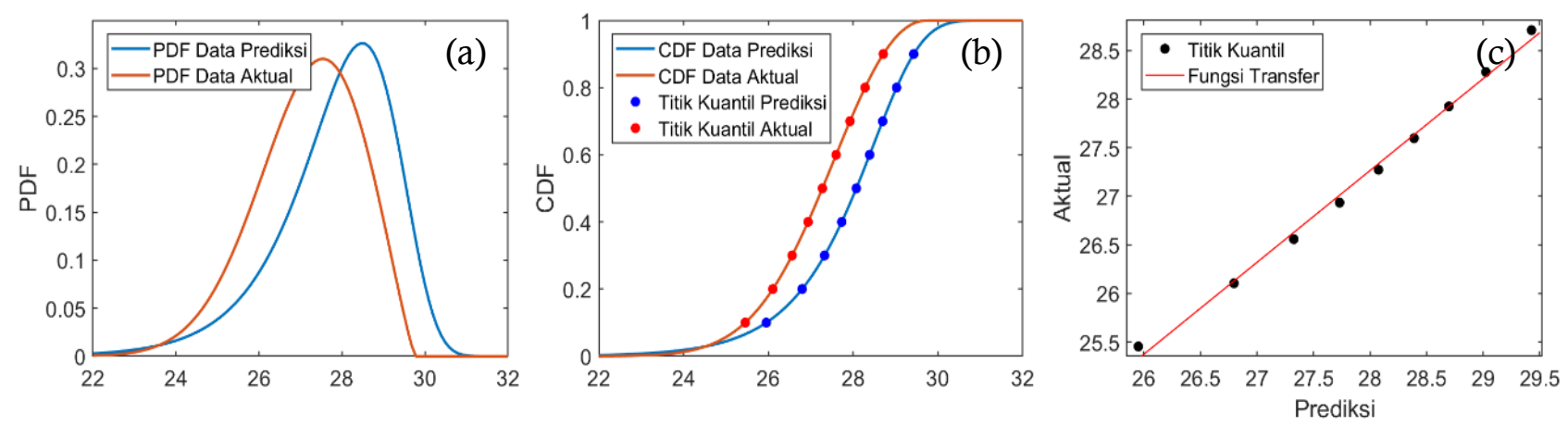

Gambar 1. Langkah koreksi bias statistik menggunakan metode quantile mapping

\subsection{Tahapan Penelitian}

Sebelum melakukan koreksi bias, data ECMWF diekstraksi menggunakan perangkat lunak berbasis numerik. Ekstraksi tersebut meliputi pemotongan wilayah IOD barat dan timur, penghitungan nilai rata-rata bulanan data ECMWF untuk setiap lead times, serta penyusunan matriks data prediksi suhu permukaan laut di wilayah IOD barat dan timur. Proses ekstraksi serupa juga dilakukan pada data HadISST. Ekstraksi tersebut meliputi pemotongan wilayah IOD barat dan timur dan pemotongan tahun, yaitu dari tahun 1982-2018, penghitungan nilai rata-rata bulanan data, serta penyusunan matriks data suhu permukaan laut di wilayah IOD barat dan timur. Kedua data dibagi menjadi 2 kelompok yaitu data training untuk tahun 1982-2011 dan data testing untuk tahun 2012-2018. Data training digunakan untuk membentuk fungsi transfer antara data ECMWF dan HadISST. Sementara itu, data testing digunakan untuk menerapkan fungsi transfer tersebut. Selanjutnya, dihitung prediksi DMI dari data sebelum dan sesudah dikoreksi beserta nilai akurasi masing-masing.

Setelah data diekstraksi, langkah pertama untuk melakukan koreksi bias dengan metode quantile mapping adalah mengidentifikasi distribusi sebaran dari data training. Data diidentifikasi distribusinya berdasarkan kelompok data yang telah diperoleh ketika proses ekstraksi data menggunakan beberapa persamaan distribusi parametrik seperti Tabel 1 berikut (Arreyndip \& Joseph, 2016; Kollu et al., 2012; Walpole, 1990). Proses identifikasi distribusi dilakukan untuk setiap bulan dan lead times di wilayah IOD barat dan timur pada data ECMWF dan HadISST. Parameter dari masing-masing fungsi sebaran diestimasi menggunakan metode maximum of log-likelihood estimator (MLE). Serta, fungsi sebaran yang paling mendekati data dipilih berdasarkan nilai negative of log-likelihood (NLogL), Kolmogorov-Smirnov error (KSE), koefisien determinasi $\left(R^{2}\right)$, khi-kuadrat $\left(x^{2}\right)$ dan root mean squared error (RMSE) (Nurdiati, Sopaheluwakan, \& Najib, 2019). Dari fungsi distribusi tersebut, akan diambil nilai kuantil dari CDF untuk digunakan sebagai data pembentukan fungsi transfer.

Tabel 1. Persamaan distribusi yang digunakan untuk mengidentifikasi distribusi data training ECMWF dan HadISST

\begin{tabular}{ll}
\hline Nama Distribusi & Fungsi Kepekatan Peluang (PDF) \\
\hline Extreme Value & $f(x \mid \mu, \sigma)=\sigma^{-1} \exp ((x-\mu) / \sigma) \exp (-\exp ((x-\mu) / \sigma))$ \\
Logistik & $f(x \mid k, \mu, \sigma)=\frac{1}{\sigma} \exp \left(-\left\{1+k \frac{x-\mu}{\sigma}\right\}^{-\frac{1}{k}}\right)\left(1+k \frac{x-\mu}{\sigma}\right)^{-1-\frac{1}{k}}$ \\
Normal & $\left.f(x \mid \mu, \sigma)=\exp \{x-\mu) / \sigma\} /\{\sigma(1+\exp \{x-\mu) / \sigma\})^{2}\right\}$ \\
Eksponensial & $f(x \mid \mu, \sigma)=(\sigma \sqrt{2 \pi})^{-1} \exp \left\{-(x-\mu)^{2} /\left(2 \sigma^{2}\right)\right\}$ \\
Gamma & $f(x \mid \mu)=\mu^{-1} \exp \left(-x \mu^{-1}\right)$ \\
Invers Gaussian & $f(x \mid \alpha, \beta)=\left(\Gamma(\alpha) \beta^{\alpha}\right)^{-1} x^{\alpha-1} \exp (-x / \beta)$ \\
Log-Normal & $f(x \mid \mu, \lambda)=\sqrt{\lambda /\left(2 \mu^{2} x\right)} \exp \left\{-\lambda(x-\mu)^{2} /\left(2 \mu^{2} x\right)\right\}$ \\
Log-Logistik & $f(x \mid \mu, \sigma)=(x \sigma \sqrt{2 \pi})^{-1} \exp \left(-(\ln x-\mu)^{2} /\left(2 \sigma^{2}\right)\right)$ \\
Weibull & $f(x \mid \mu, \sigma)=\frac{1}{x \sigma} \frac{\exp \left(\frac{\log (x)-\mu}{\sigma}\right)}{\left(1+\exp \left\{\frac{\log (x)-\mu}{\sigma}\right\}\right)^{2}}$ \\
\hline
\end{tabular}


Setelah diperoleh masing-masing sebaran, langkah kedua adalah membentuk fungsi transfer dari sebaran ECMWF dan HadISST. Fungsi transfer yang baik digunakan untuk menghubungkan data prediksi dan aktual data suhu permukaan air laut adalah fungsi linear (Nurdiati, Sopaheluwakan, \& Najib, 2019). Misalkan, $X$ dan $Y$ masing-masing adalah vektor data dari nilai-nilai kuantil sebaran data training ECMWF dan HadISST, maka persamaan linear yang dimaksud adalah

$Y=f(X)=a X+b$

dengan $a$ dan $b$ merupakan suatu konstanta. Kedua nilai konstanta tersebut ditentukan menggunakan metode regresi linear. Selanjutnya, fungsi transfer tersebut dikatakan baik dan dapat digunakan untuk mengoreksi bias data testing jika koefisien determinasi $\left(R^{2}\right)$ fungsi transfer bernilai lebih dari $70 \%$ (Dasanto et al., 2014).

Setelah didapatkan fungsi transfer untuk setiap bulan dan lead times pada wilayah IOD barat dan timur, fungsi transfer tersebut selanjutnya digunakan untuk mengoreksi data testing ECMWF dari tahun 2013-2018. Data testing dievaluasi pada fungsi transfer yang diperoleh untuk setiap titik ensemble, longitude dan latitude sesuai dengan bulan dan lead times. Selanjutnya, hasil evaluasi tersebut dirata-rata untuk setiap titik longitude dan latitude, sehingga diperoleh prediksi ensemble suhu permukaan air laut setelah dikoreksi di wilayah IOD barat dan timur. Sebagai perbandingan, dihitung pula rataan data prediksi sebelum dikoreksi di wilayah IOD barat dan timur. Untuk melihat akurasi dari koreksi bias pada data ECMWF, prediksi ensemble suhu permukaan air laut sebelum dan sesudah dikoreksi dibandingkan dengan data aktualnya, yaitu rataan suhu permukaan air laut di wilayah IOD barat dan timur dari data HadISST testing.

Terakhir, dihitung DMI dari data prediksi suhu permukaan air laut sebelum dan sesudah dikoreksi. DMI merupakan indeks yang menggambarkan perbedaan antara anomali data suhu permukaan air laut di wilayah IOD barat dan timur (Saji et al., 1999). Anomali data suhu permukaan air laut adalah selisih antara data permukaan air laut terhadap rataan klimatologi (rataan suhu permukaan air laut selama 30 tahun). Dasar rataan klimatologi yang digunakan pada penelitian ini adalah tahun 1982-2011, sehingga anomali data suhu permukaan air laut di wilayah IOD barat dan timur adalah

$T_{\text {barat }}^{*}=T_{\text {barat }}-\bar{T}_{\text {barat }}$

$T_{\text {timur }}^{*}=T_{\text {timur }}-\bar{T}_{\text {timur }}$

dengan $T_{\text {barat }}^{*}$ dan $T_{\text {timur }}^{*}$ adalah anomali suhu permukaan air laut di IOD barat dan timur, $T_{\text {barat }}$ dan $T_{\text {timur }}$ adalah suhu permukaan air laut di IOD barat dan timur serta $\bar{T}_{\text {barat }}$ dan $\bar{T}_{\text {timur }}$ adalah rataan klimatologi (rata-rata suhu permukaan air laut tahun 1982-2011) di IOD barat dan timur. Dengan demikian, prediksi DMI dapat dihitung menggunakan data anomali IOD barat dan timur, yaitu

$D M I=T_{\text {barat }}^{*}-T_{\text {timur }}^{*}$

\section{Hasil dan Pembahasan}

\subsection{Ekstraksi data}

Hasil ekstraksi data ECMWF adalah kumpulan data dalam suatu sel berdasarkan bulan dan lead times dari data prediksi suhu permukaan laut di wilayah IOD barat dengan ukuran sel 12 (bulan) $\times 7$ (lead times) dan masing-masing sel berisi 4920750 data serta IOD timur dengan ukuran sel 12 (bulan) $\times$ 7 (lead times) dan masing-masing sel berisi 2490750 data. Sementara itu, hasil ekstraksi data HadISST adalah kumpulan data dalam suatu sel berdasarkan bulan dari data suhu permukaan laut HadISST di wilayah IOD barat dengan ukuran sel 12 (bulan) dan masing-masing sel berisi 12000 data serta IOD timur dengan ukuran sel 12 (bulan) dan masing-masing sel berisi 6000 data. Selanjutnya, kedua data tersebut dibagi menjadi dua kelompok yaitu data training untuk tahun 1982-2011 dan testing untuk tahun 2012-2018.

\subsection{Identifikasi distribusi}

Gambar 2 menunjukkan hasil identifikasi data ECMWF di wilayah IOD barat pada lead time ke-1 untuk bulan Januari-Desember. Dapat dilihat bahwa kecenderungan data prediksi ECMWF pada lead time ke-1 dapat dihampiri menggunakan distribusi extreme value. Sementara itu, pada lead times ke- 2 hingga ke-7, kecenderungan data prediksi ECMWF dapat dihampiri menggunakan distribusi extreme value, generalized extreme value, dan Weibull. Hasil serupa juga didapatkan untuk IOD timur. Data suhu permukaan air laut di wilayah IOD timur cenderung dapat dihampiri menggunakan distribusi extreme 

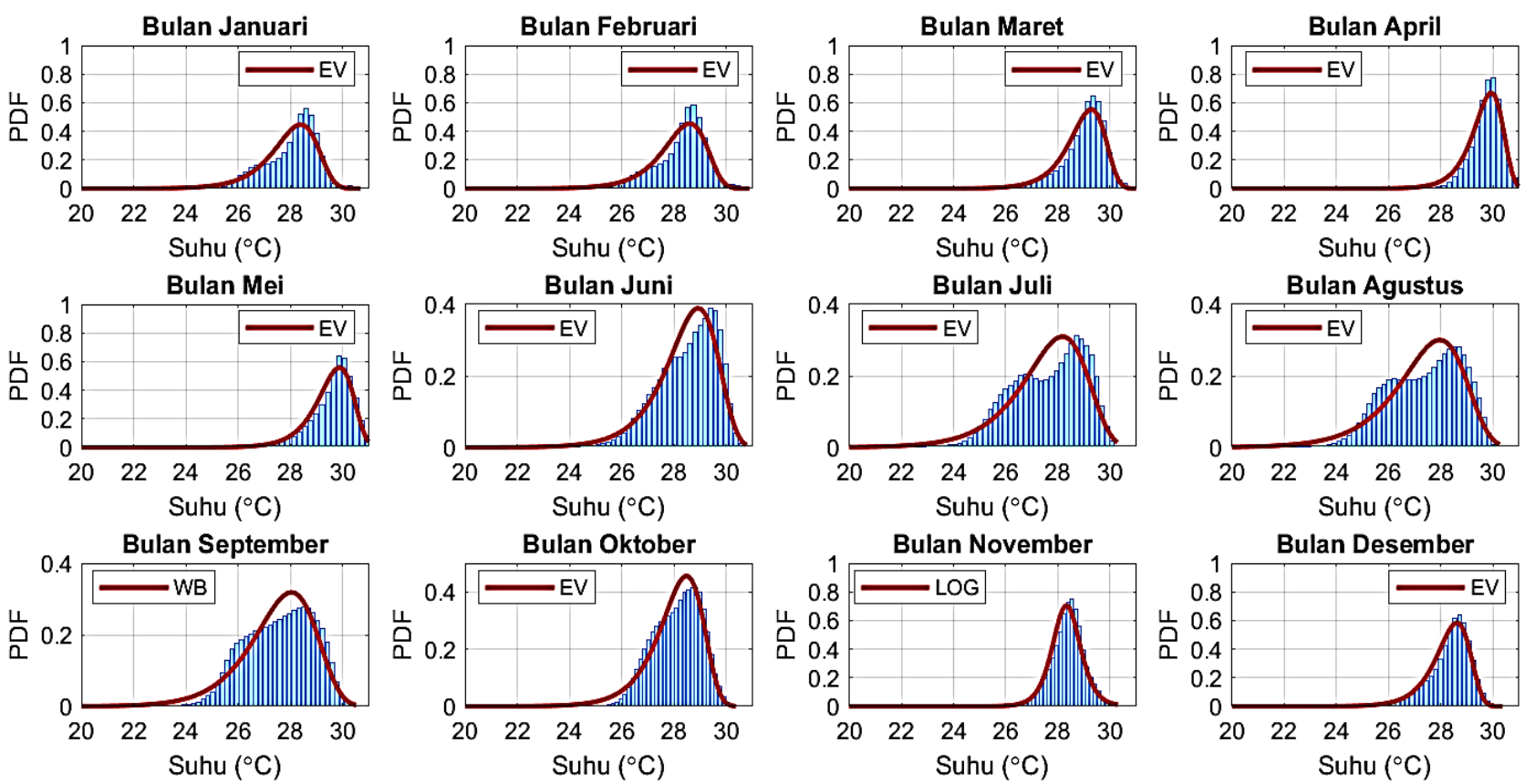

Gambar 2. Hasil identifikasi distribusi data prediksi ECMWF di wilayah IOD barat pada lead time ke-1 bulan Januari hingga Desember

value. Perbedaan jenis dan bentuk sebaran pada setiap bulan disebabkan oleh perbedaan karakteristik data-data tersebut, seperti kemiringan dan kesimetrisan bentuk sebaran.

\subsection{Pembentukan fungsi transfer}

Kuantil didefinisikan sebagai invers dari CDF. Misalkan, $X$ merupakan peubah acak kontinu dengan fungsi sebaran $F(x)$, maka kuantil ke- $p$ dari $X$ adalah $Q(p)=F^{-1}(p)$ untuk $0<p<1$. Kuantil juga dapat diartikan sebagai nilai yang membagi suatu data menjadi $n$ kelompok data yang sama besar. Kasus khusus dari kuantil adalah persentil, yaitu kuantil yang membagi data menjadi 100 kelompok data. Selain persentil, ada juga desil yang membagi data menjadi 10 kelompok data, kuartil 4 kelompok data dan median 2 kelompok data. Jadi, kuantil merupakan bentuk umum dari persentil, desil, maupun kuartil. Berdasarkan beberapa percobaan yang dilakukan, kuantil sebanyak 40 bagian atau setiap $2.5 \%$ dengan nilai batas bawah 0.001 dan batas atas 0.999 memberikan hasil yang paling efektif dan efisien. Dengan demikian, nilai $p$ yang akan digunakan adalah $0.001,0.025,0.05, \ldots, 0.975$, dan 0.999 .
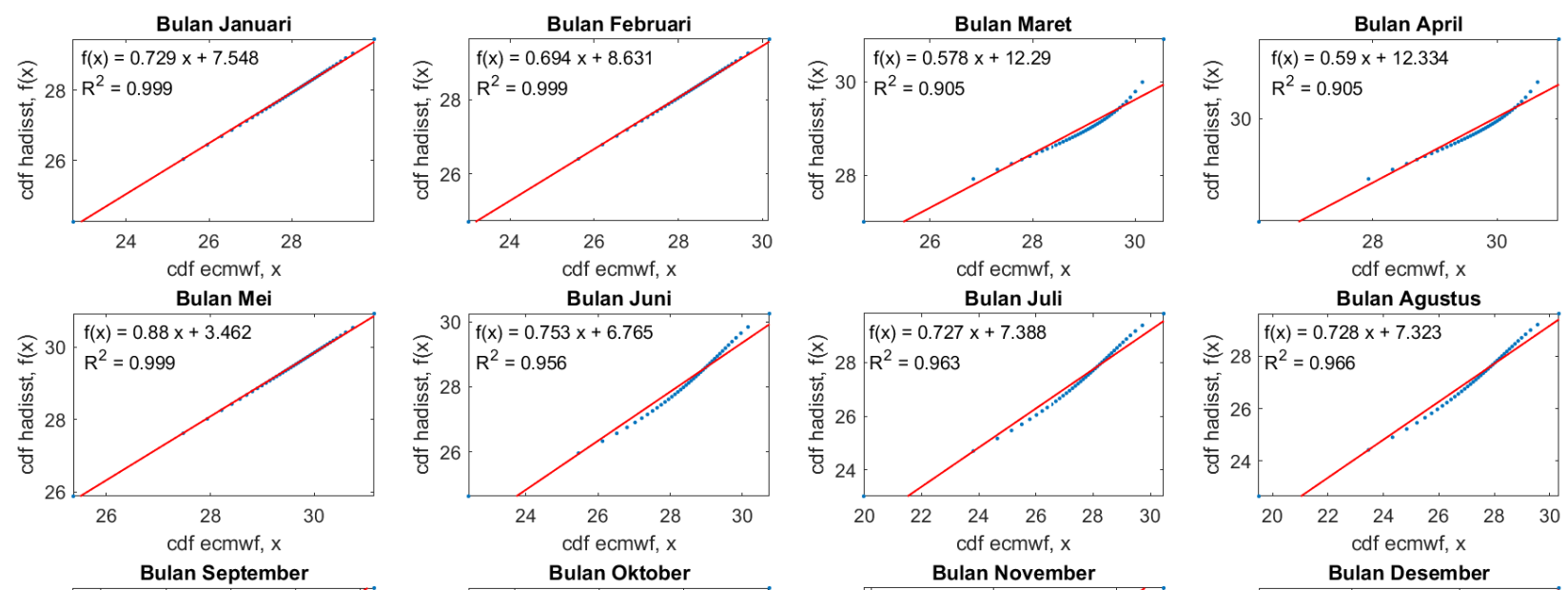

Bulan September
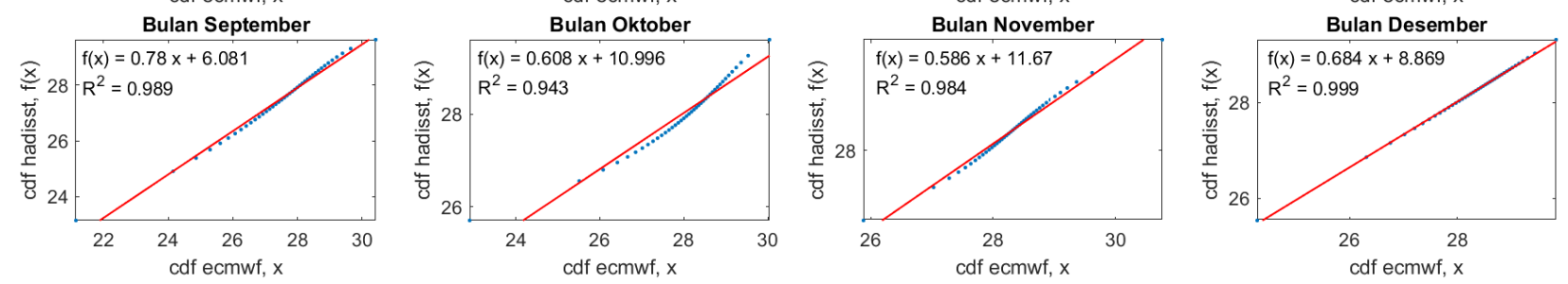

Gambar 3. Fungsi transfer data ECMWF dan HadISST di wilayah IOD barat pada lead time ke-1 untuk bulan Januari hingga Desember 

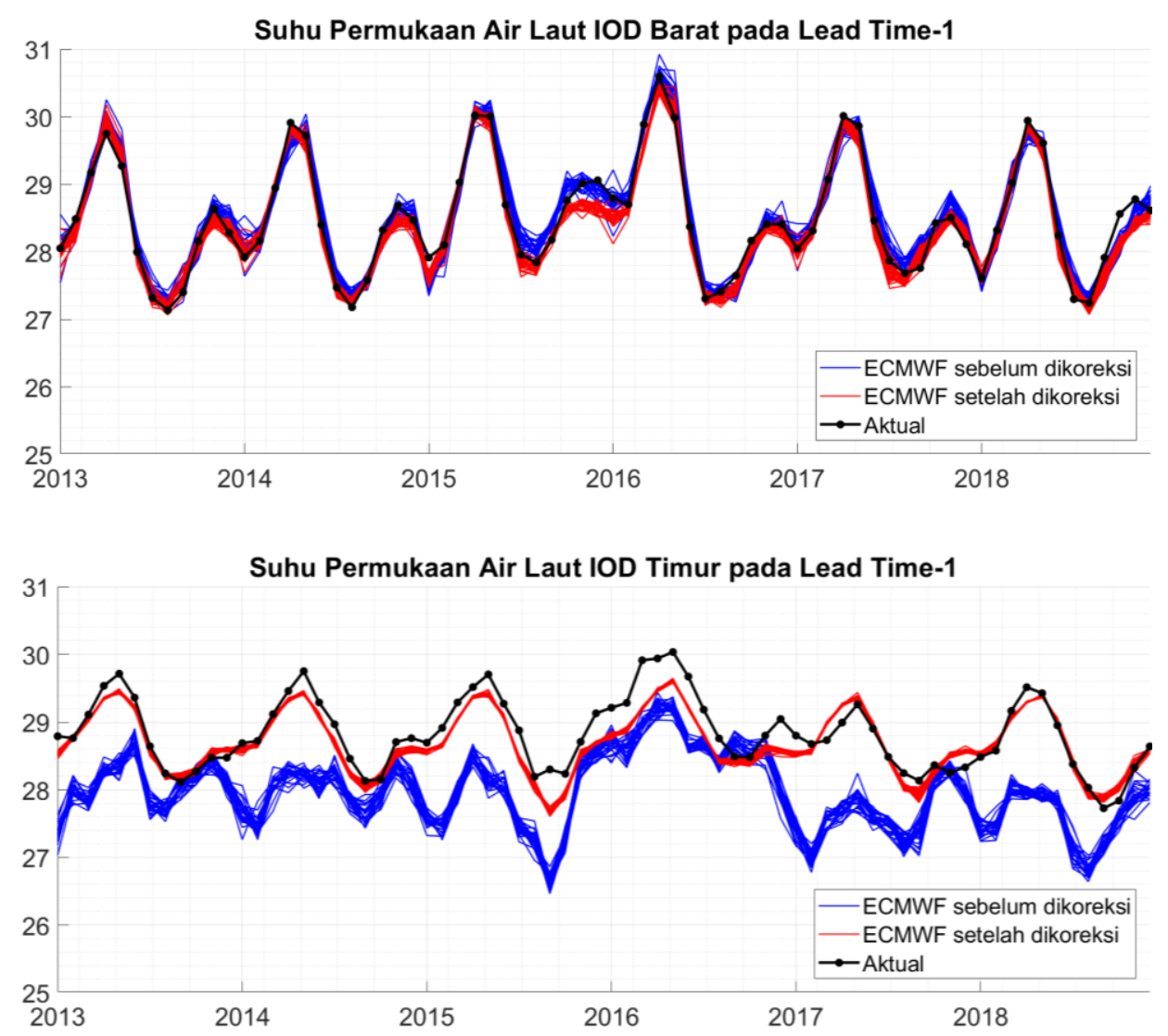

Gambar 4. Perbandingan data prediksi ECMWF sebelum dan setelah dikoreksi menggunakan metode quantile maping pada lead time ke-1 terhadap rataan suhu aktual di IOD barat dan timur

Hasil pembentukan fungsi transfer data ECMWF dan HadISST di wilayah IOD barat pada lead time ke-1 bulan Januari hingga Desember dapat dilihat pada Gambar 3. Fungsi transfer yang didapatkan pada lead time ke-1 di wilayah IOD barat memiliki koefisien determinasi lebih dari $70 \%$. Lebih lanjut, fungsi transfer pada lead times ke-2 hingga 7 juga memiliki koefisien determinasi lebih dari $70 \%$. Hal yang sama juga terjadi di wilayah IOD timur, sehingga semua fungsi transfer dapat digunakan pada proses selanjutnya.

\subsection{Koreksi bias data testing}

Perbandingan data prediksi ECMWF sebelum dan setelah dikoreksi menggunakan metode quantile maping pada lead time ke-1 terhadap rataan suhu aktual di wilayah IOD barat dan timur dapat dilihat pada Gambar 4. Pada gambar tersebut, dapat diamati bahwa bias dari prediksi suhu permukaan air di wilayah IOD barat sangat kecil dan sudah memiliki akurasi yang baik, karena data aktual sudah berada pada jangkauan prediksi ensemble. Namun, pada wilayah IOD timur, bias prediksi suhu permukaan air laut sangat tinggi dan tidak akurat. Akan tetapi, proses koreksi bias mampu membawa prediksi ECMWF mendekati suhu permukaan air laut aktual. Hasil koreksi data prediksi suhu permukaan air laut di wilayah IOD barat dan timur pada lead time ke-2 hingga ke-7 memiliki pola yang sama seperti pada lead time ke-1, yaitu perbaikan yang signifikan di wilayah IOD timur, sedangkan pada wilayah IOD barat, perbaikan tidak terlalu signifikan.

\subsection{Prediksi Dipole Mode Index (DMI) dan akurasinya}

Perbandingan DMI menggunakan data prediksi ECMWF sebelum dan setelah dikoreksi dengan metode quantile maping pada lead time 1 dan 2 terhadap data DMI aktual dapat dilihat pada Gambar 5. Berdasarkan Gambar 5, prediksi DMI dari data terkoreksi lebih mendekati data aktual daripada data sebelum dikoreksi. Pola yang serupa juga telihat pada lead time ke-3 hingga ke-7.

Untuk membandingkan hasil prediksi DMI dari kedua data, Gambar 6 menunjukkan nilai expected error prediksi DMI dari data sebelum dan sesudah dikoreksi untuk setiap bulan dan lead times. Prediksi DMI menggunakan data sebelum dikoreksi memiliki expected error yang tinggi. Warna hitam menunjukkan bahwa ekspektasi kesalahan dari prediksi bernilai kurang dari 0.3 yang artinya prediksi memiliki akurasi yang tinggi. Terlihat bahwa prediksi DMI menggunakan data ECMWF hanya lima 

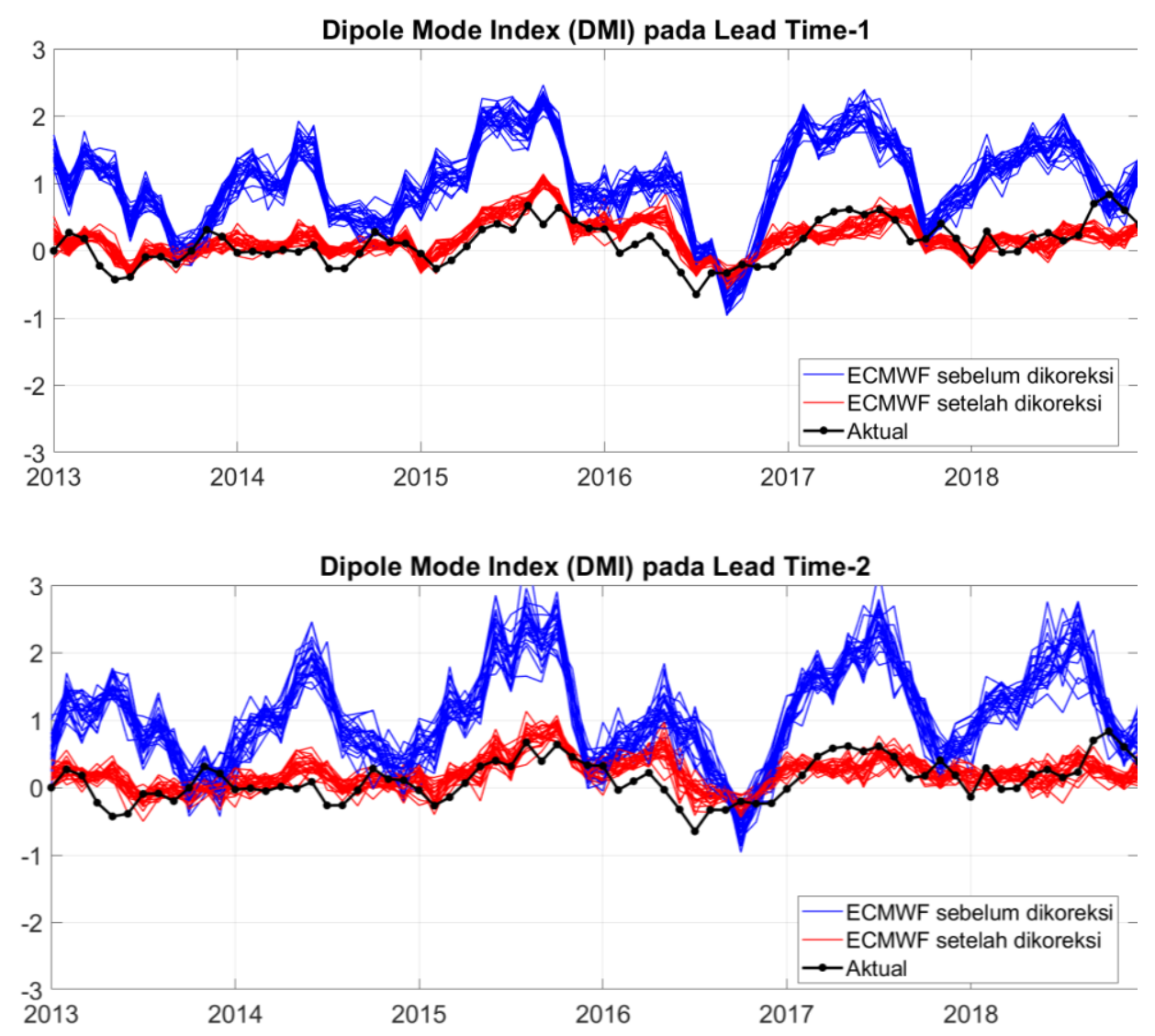

Gambar 5. Perbandingan DMI menggunakan data prediksi ECMWF sebelum dan setelah dikoreksi menggunakan metode quantile maping pada lead time ke-1 dan ke-2 terhadap data DMI aktual

titik yang memiliki nilai expected error kurang dari 0.3. Sebaliknya pada prediksi DMI menggunakan data terkoreksi, nilai expected error yang dihasilkan jauh lebih rendah daripada nilai expected error prediksi DMI menggunakan data sebelum dikoreksi. Hal ini menunjukkan akurasi prediksi DMI menggunakan data terkoreksi lebih baik dibandingkan prediksi DMI menggunakan data ECMWF.

\section{Kesimpulan}

Berdasarkan hasil koreksi bias pada data prediksi suhu permukaan air laut, wilayah IOD timur memiliki bias yang lebih besar dan signifikan dibandingkan wilayah IOD barat. Dengan demikian, bias yang terdapat pada prediksi DMI lebih dipengaruhi oleh bias yang terdapat pada data prediksi suhu permukaan air laut di wilayah IOD timur dibandingkan IOD barat. Lebih lanjut, prediksi DMI menggunakan data ECMWF yang telah dikoreksi memberikan hasil yang lebih baik dibandingkan

Expected absolute error data sebelum dikoreksi

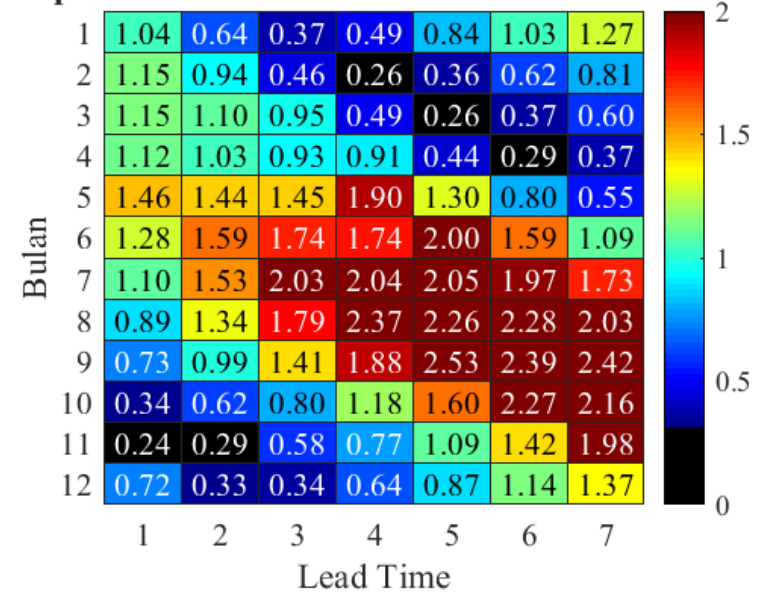

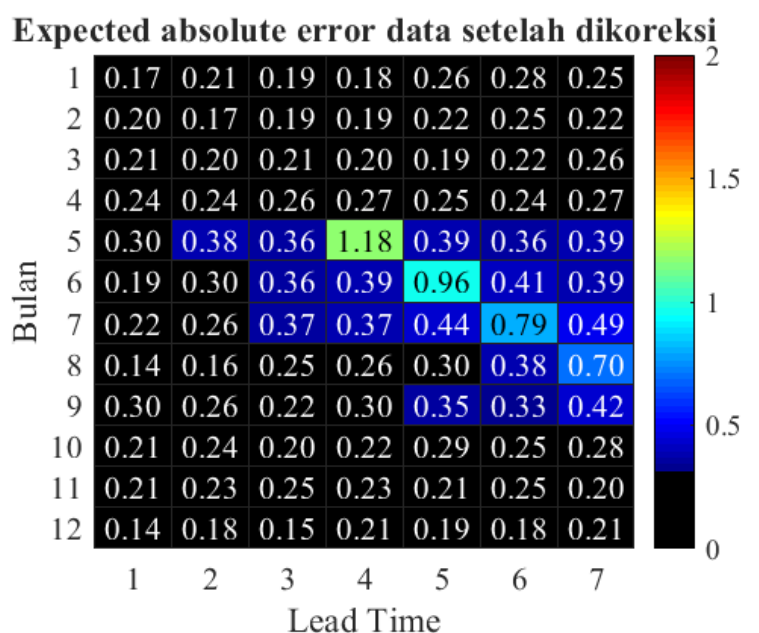

Gambar 6. Nilai expected absolute error dari prediksi DMI menggunakan data sebelum dan sesudah dikoreksi untuk setiap bulan dan lead times 
dengan data ECMWF sebelum dikoreksi. Berdasarkan nilai expected error, prediksi DMI menggunakan data ECMWF yang telah dikoreksi memiliki nilai expected error yang lebih rendah dibandingkan prediksi DMI menggunakan data ECMWF sebelum dikoreksi untuk semua bulan dan lead times. Selain itu, prediksi DMI menggunakan data ECMWF yang telah dikoreksi memiliki akurasi yang tinggi untuk memprediksi kejadian IOD pada bulan Oktober-April.

\section{Ucapan Terima Kasih}

Penulis berterima kasih kepada Dr. Ardhasena Sopaheluwakan dan Pandu Septiawan M.Si atas bantuan dan masukan yang diberikan. Penghargaan juga diberikan kepada Met Office Hadley Centre observations datasets untuk dataset HadISST serta Pusat Penelitian dan Pengembangan, Badan Klimatologi Meteorologi dan Geofisika (BMKG) Indonesia untuk dataset ECMWF.

\section{Referensi}

Arreyndip, N. A., \& Joseph, E. (2016). Generalized extreme value distribution models for the assessment of seasonal wind energy potential of Debuncha, Cameroon. Journal of Renewable Energy.

Bramawanto, R., \& Abida, R. F. (2017). Tinjauan Aspek Klimatologi (ENSO dan IOD) dan Dampaknya Terhadap Produksi Garam Indonesia. Jurnal Kelautan Nasional, 12(2), 91-99.

Buizza, R., Leutbecher, M., \& Isaksen, L. (2008). Potential use of an ensemble of analyses in the ECMWF Ensemble Prediction System. Quarterly Journal of the Royal Meteorological Society: A Journal of the Atmospheric Sciences, Applied Meteorology and Physical Oceanography, 134(637), 2051-2066.

Dasanto, B. D., Boer, R., Pramudya, B., \& Suharnoto, Y. (2014). Evaluasi Curah Hujan TRMM Menggunakan Pendekatan Koreksi Bias Statistik. Jurnal Tanah Dan Iklim, 38(1), 15-24.

Dee, D. P. (2004). Variational bias correction of radiance data in the ECMWF system. Proceedings of the ECMWF Workshop on Assimilation of High Spectral Resolution Sounders in NWP, Reading, UK, 28, 97112.

Dippe, T., Greatbatch, R. J., \& Ding, H. (2019). Seasonal prediction of equatorial Atlantic sea surface temperature using simple initialization and bias correction techniques. Atmospheric Science Letters, 20(5), e898.

Kollu, R., Rayapudi, S. R., Narasimham, S., \& Pakkurthi, K. M. (2012). Mixture probability distribution functions to model wind speed distributions. International Journal of Energy and Environmental Engineering, 3(1), 27.

Lealdi, D., Nurdiati, S., \& Sopaheluwakan, A. (2018). Statistical bias correction modelling for seasonal rainfall forecast for the case of Bali island. Journal of Physics: Conference Series, 1008, 12-18. https://doi.org/10.1088/1742-6596/1008/1/012018

Macias, D., Garcia-Gorriz, E., Dosio, A., Stips, A., \& Keuler, K. (2018). Obtaining the correct sea surface temperature: Bias correction of regional climate model data for the Mediterranean Sea. Climate Dynamics, 51(3), 1095-1117.

McNally, A. P., Derber, J., Wu, W., \& Katz, B. (2000). The use of TOVS level-1b radiances in the NCEP SSI analysis system. Quarterly Journal of the Royal Meteorological Society, 126(563), 689-724.

Misnawati, M., Boer, R., June, T., \& Faqih, A. (2018). Perbandingan metodologi koreksi bias data curah hujan chirps. LIMNOTEK-Perairan Darat Tropis Di Indonesia, 25(1).

Nurdiati, S., Sopaheluwakan, A., \& Najib, M. K. (2019). Statistical Bias Correction for Predictions of Indian Ocean Dipole Index With Quantile Mapping Approch. International MIPAnet Conference on Science and Mathematics (IMC-SciMath), Medan.

Nurdiati, S., Sopaheluwakan, A., \& Pratama, Y. A. (2019). Statistical Bias Correction On Global Climate Model For El Nino Index Predictions. The 15th IMT-GT International Conference on Mathematics, Statistics, and their Applications (ICMSAdasan), Bogor.

Ogutu, G. E., Franssen, W. H., Supit, I., Omondi, P., \& Hutjes, R. W. (2017). Skill of ECMWF system-4 ensemble seasonal climate forecasts for East Africa. International Journal of Climatology, 37(5), 2734-2756.

Piani, C., Haerter, J. O., \& Coppola, E. (2010). Statistical bias correction for daily precipitation in regional climate models over Europe. Theoretical and Applied Climatology, 99(1-2), 187-192. https://doi.org/10.1007/s00704-009-0134-9

Saji, N., Goswami, B., Vinayachandran, P., \& Yamagata, T. (1999). A dipole mode in the tropical Indian Ocean. Nature, 401(6751), 360-363. 
Stockdale, T. N., Anderson, D. L., Balmaseda, M. A., Doblas-Reyes, F., Ferranti, L., Mogensen, K., Palmer, T. N., Molteni, F., \& Vitart, F. (2011). ECMWF seasonal forecast system 3 and its prediction of sea surface temperature. Climate Dynamics, 37(3-4), 455-471.

Walpole, R. E. (1990). Pengantar statistika, edisi ke-3 (Introduction to statistics). PT Gramedia Pustaka Utama. https://books.google.co.id/books?id=hzwjcgAACAAJ 